\title{
In Vitro Culture of Vriesea gigantea and Vriesea philippocoburgii: Two Vulnerable Bromeliads Native to Southern Brazil
}

\author{
Annette Droste ${ }^{1,2^{*}}$, Anelise Machado da Silva ${ }^{2}$, Adriana Vieira Matos ${ }^{2}$ and Júlia Winck de \\ Almeida ${ }^{2}$ \\ ${ }^{I}$ Programa de Pós-Graduação em Biologia; ${ }^{2}$ Laboratório de Cultura de Tecidos Vegetais; UNISINOS; C. P. 275; \\ 93001-970; São Leopoldo - RS - Brasil
}

\begin{abstract}
Micropropagation studies were carried out using the seeds for establishing an in vitro culture of Vriesea gigantea and Vriesea philippocoburgii. Germination rate of $\mathrm{V}$. gigantea was higher than of $\mathrm{V}$. philippocoburgii. Plantlets of V. philippocoburgii gave rise to many adventitious shoots when cultivated in Knudson basal medium. In contrast, for $\mathrm{V}$. gigantea, a higher salts-concentration was needed, so that the number of shoots was increased by Murashige and Skoog medium. Addition of activated charcoal and naphthaleneacetic acid in regeneration medium allowed the growth of shoots and the formation of roots, confirming the success of in vitro culture. The differences in expression of the genotypes reinforce the need of more research in order to set up the conditions that could offer the best response of the specific tissues.
\end{abstract}

Key words: In vitro culture, conservation, propagation, Bromeliaceae, Vriesea

\section{INTRODUCTION}

The damaging effect of human activities on natural habitats has resulted in a great number of fragile plants, including species of the Bromeliaceae family. In addition to this, plants with ornamental qualities are collected intensively and illegally, leading to alterated plant communities (Fay, 1994). Vriesea gigantea Gaudich. and Vriesea philippocoburgii Wawra are two native bromeliads from the state of Rio Grande do Sul, in Southern Brazil, which belong to the category of epiphytic tank species. Like other species of the genus Vriesea, they produce seeds with low capacity of germination (Mekers, 1977; Mercier and Kerbauy, 1995). After flowering, only one or two offshoots are formed and develop very slowly. Because their highly ornamental qualities, these bromeliads are collected intensively from natural habitat and the conventional methods of propagation cannot supply the marked. Thus, $V$. gigantea and $V$. philippocoburgii may be viewed as threatened species (Rio Grande do Sul, 2003).

Different in vitro methods have been used to achieve the conservation or multiplication of specific genotypes of other bromeliads (Mekers, 1977; Hosoki and Asahira, 1980; Mercier and Kerbauy, 1992, 1994, 1995; Carneiro et al., 1999; Arrabal et al., 2002). When initiation of the culture is done through seeds obtained from a wide range of capsules, many different genotypes can be conserved in vitro (Fay, 1994; Pence, 1999). Otherwise, through the multiplication of seedlings

\footnotetext{
${ }^{*}$ Author for correspondence
} 
obtained in vitro, a large number of genetically homogeneous plants can be obtained.

Due to the great commercial importance and the status of conservation of $V$. gigantea and $V$. philippocoburgii, there is a special interest in in vitro culture as an alternative for the production of plants. For both species, tissue culture has been used as a tool to investigate physiological aspects of nitrogen nutrition and endogenous hormones (Mercier et al., 1997; Mercier and Kerbauy, 1998; Endres et al., 2002). In the reports, the medium used was Knudson (1946), based on studies with other species of the genus Vriesea. In the present study, we compared the preference of these bromeliads for different medium-compositions in order to evaluate the potential of tissue culture as an alternative to produce plants.

\section{MATERIALS AND METHODS}

Plant material and culture conditions. Mature capsules of $V$. gigantea and $V$. philippocoburgii were surface sterilized for $30 \mathrm{sec}$ in $70 \%$ ethanol and $15 \mathrm{~min}$ in $4 \%$ sodium hypochlorite plus $0.1 \%$ Tween-20, followed by four rinses in sterile distilled water. Seeds were extracted from capsules and placed on semi-solid media after cutting their appendices off. Two independent experiments were conducted. In Experiment I, seeds of both species were germinated on basal $\mathrm{K}$ medium (Knudson, 1946), testing modifications in salts and the addition of vitamins, as following: $(\mathrm{K}) \mathrm{K}$ medium; (K/MS micro) K macro-nutrients with MS (Murashige and Skoog, 1962) micro-nutrients; (K/MS vit) $\mathrm{K}$ medium added by MS vitamins. All media were supplemented with $2 \%$ sucrose, $1.2 \%$ agar, at pH 6.4 (before autoclaving). For Experiment II, seeds of $V$. gigantea were used. Part of the capsules was submitted to cold pretreatment. Three capsules were maintained for 7 , 14 and 21 days at $4^{\circ} \mathrm{C}$, when seeds were placed on germination medium. As control, seeds from three capsules were placed on media immediately after sterilization. Germination was made on MS medium with different concentrations of macronutrients and vitamin-compositions: (MS) MS medium full strength; (1/2 MS) MS medium with macro-nutrients at half strength; (MSB5) MS salts with B5 (Gamborg et al., 1968) vitamins. MS and $1 / 2$ MS were supplemented with $2 \%$ sucrose, whereas MSB5 was supplemented with $3 \%$ sucrose. All media were gelified with $1.2 \%$ agar, at $\mathrm{pH} 6.4$ (before autoclaving). The number of seeds tested for each treatment in Experiments I and II is shown in Tables 1 and 2, respectively.

The cultures from both experiments were maintained on the media for 45 days at $26 \pm 1^{\circ} \mathrm{C}$ in a $16 \mathrm{~h}$ light regime at a light intensity of 22.5 $\mu \mathrm{Em}^{-2} \mathrm{~s}^{-1}$. After this period, the germinated seeds were counted and the seedlings were transferred to media with hormones to allow the production of adventitious shoots.

Multiplication of adventitious shoots. After 45 days of culture, seedlings were transferred individually to test tubes containing $8 \mathrm{ml}$ of medium. Tissues obtained from Experiment I were placed on $\mathrm{K}, \mathrm{K} / \mathrm{MS}$ micro and K/MS vit, respectively, containing $2 \mathrm{mg} / \mathrm{L} \mathrm{BAP}, 0.5 \mathrm{mg} / \mathrm{L}$ NAA, $2 \%$ sucrose, at $\mathrm{pH} 6.4$ (before autoclaving). Seedlings obtained from the three different media tested in Experiment II were randomly transferred to $\mathrm{MS}$ and $1 / 2 \mathrm{MS}$, containing $2 \mathrm{mg} / \mathrm{L} \mathrm{BAP}, 0.5$ $\mathrm{mg} / \mathrm{L}$ NAA, 2\% sucrose, at $\mathrm{pH} 6.4$ (before autoclaving). The concentrations of hormones used in the present study were based on positive results for shoot multiplication in other species of the genus Vriesea (Mercier and Kerbauy, 1992, 1994). Subcultures to media with the same composition were performed at monthly intervals, over four months. The number of tubes/medium varied from 20 to 23. Multiplication efficiency was calculated as the percentage of seedlings that gave rise to adventitious shoots as well as the mean number of shoots/seedling.

Data of percentage of seedlings that produced adventitious shoots were analyzed using the chisquare test. The number of adventitious shoots/ seedling was analyzed using the one-way analysis of variance ( $V$. philippocoburgii) and KruskalWallis non parametric analysis of variance $(V$. gigantea) and the comparison among species were made using the Mann-Whitney test.

Plant development from adventitious shoots. After six months of culture, the adventitious shoots obtained from Experiment I and II were transferred to $\mathrm{K}$ medium and $\mathrm{MS}$ medium, respectively, containing $0.2 \mathrm{mg} / \mathrm{L}$ NAA, $2 \%$ sucrose, $0.5 \%$ activated charcoal, $1.2 \%$ agar at $\mathrm{pH}$ 6.4 (before autoclaving). After three months, a subculture to medium with the same composition was made for further three months. Whole plants were transplanted to plastic cups containing vermiculite, covered with plastic film. Plants were gradually exposed to ambient humidity over one week and than transferred to plastic pots with soil. 


\section{RESULTS AND DISCUSSION}

In vitro germination. Seed germination initiated eight-then days after sowing and occurred on all media tested, resulting in the production of one plant per seed. In Experiment I, both $V$. gigantea and $V$. philippocoburgii showed high germination rates (99 and 89\%, respectively) (Table 1). For $V$. gigantea, cold pre-treatment did not cause any increase of germination rate (Table 2). Nevertheless, a shorter time was necessary to induce germination when compared with seeds not exposed to cold pre-treatment (data not shown). The low germination percentage obtained in $1 / 2$ MS was due to contamination of seeds from one loculus of the capsule. The results showed that capsules could be stocked in freezer, which could be interesting when a high number of samples were collected and a longer time was needed to process and place all material in culture.

The percentages of germination obtained here were similar to that obtained previously in the literature. Mercier and Kerbauy (1994) registered up to $90 \%$ of germination for $V$. hieroglyphica using $1 / 2 \mathrm{~K}$ and $1 / 4 \mathrm{~K}$ media, with each seed giving rise to 3-7 plantlets. For V. splendens, Mekers (1977) observed that good germination of seeds was achieved on $\mathrm{K}$ medium supplemented with MS micro-nutrients, although, without hormones, the percentage of germinating seeds was only $62 \%$. On the other hand, on MS medium, seeds germinated, but seedlings died after some weeks. The author attributed this to the sensitivity of the species to high salt- concentrations present in MS medium. When using MS media containing only $1 / 2$ or $1 / 4$ of the normal salt-concentration, Mekers (1976) obtained a greater surviving rate of plantlets.

Multiplication of adventitious shoots and development of plants. Adventitious shoot multiplication occurred in response to all media tested. The potential of multiplication, expressed by the percentage of seedlings that produced adventitious shoots ranged from 40 to $68 \%$ for $V$. gigantea and did not vary significantly among media $(\mathrm{p}=0.17)$ (Table 3). For $V$. philippocoburgii, all seedlings gave rise to adventitious shoots (Table 3). Species showed different genotypic responses to culture conditions. In Experiment I, the average number of shoots/seedling did not vary significantly among media within each species, ranging from 0.55 to 1.05 for $V$. gigantea $(\mathrm{p}=0.22)$ and from 3.60 to
5.05 for $V$. philippocoburgii $(\mathrm{p}=0.25)$. Comparing the species, $V$. gigantea and $V$. philippocoburgii showed an average of 0.72 and 4.3 shoots/seedling, respectively. These differences were statistically significant $(\mathrm{p}<0.001)$ (Table 3 ). While showing low capacity of multiplication on the different modifications of $\mathrm{K}$ medium, plantlets of $V$. gigantea gave rise to higher numbers of adventitious shoots on MS and 1/2 MS (Table 3). MS medium proved to be the best medium for this species (3.14 shoots/seedling; $p=0.047)$. Some earlier reports showed that for other species of the genus Vriesea, the surviving and multiplication rates were higher on low salt-concentration media. Mekers (1977) investigating the in vitro culture of some bromeliads, including three species of Vriesea, concluded that for multiplication of plantlets using seedlings as explants, a low saltconcentration was needed, like $1 / 3$ to $1 / 2$ of MS medium, or normal to half strength of K medium. In two other reports, twenty two shoots were formed per seedling for $V$. fosteriana after three months on $\mathrm{K}$ medium containing $2 \mathrm{mg} / \mathrm{L} \mathrm{BAP}$ and $0.5 \mathrm{mg} / \mathrm{L}$ NAA (Mercier and Kerbauy, 1992), while for $V$. hieroglyphica, seven shoots/plantlet were produced after six months in $\mathrm{K}$ medium with the same concentrations of hormones (Mercier and Kerbauy, 1994). Recent reports that focused physiological aspects of $V$. philippocoburgii and $V$. gigantea, utilized $\mathrm{K}$ medium, even normal or diluted (Mercier et al., 1997; Endres and Mercier, 2001; Endres et al., 2002; Endres and Mercier, 2003).

At the last stage of the culture, a lower concentration of NAA $(0.2 \mathrm{mg} / \mathrm{L})$ was used. Initially, adventitious shoots proliferation continued. It seems that cytokinins have a prolonged residual activity even after transferring the shoots to a cytokinin-free medium (Mekers, 1977). After three months, root and apical shoot growth occurred. Mercier and Kerbauy (1992) obtained an increase in length and in the number of roots for $V$. fosteriana, using this concentration of NAA, when compared with other levels and combinations of growth regulators.

To increment the development of the plantlets, activated charcoal was added to the medium at the last stage. Addition of activated charcoal have been reported for other species such as Anemone canadensis, Anemone hupehensis, Nicotiana tabacum (Johansson, 1983), Allium cepa, Daucus carota and Haplopappus gracilis (Fridborg and Erikson, 1975; Fridborg et al., 1978). 
Table 1 - Seed germination of Vriesea gigantea and Vriesea philippocoburgii on three medium- compositions, based on Knudson medium.

\begin{tabular}{|c|c|c|c|c|c|c|}
\hline \multirow{3}{*}{ Medium } & \multicolumn{3}{|c|}{ Vriesea gigantea } & \multicolumn{3}{|c|}{ Vriesea philippocoburgii } \\
\hline & \multirow{2}{*}{$\begin{array}{c}\text { Total number } \\
\text { of seeds }\end{array}$} & \multicolumn{2}{|c|}{ Germinated seeds } & \multirow{2}{*}{$\begin{array}{l}\text { Total number } \\
\text { of seeds }\end{array}$} & \multicolumn{2}{|c|}{ Germinated seeds } \\
\hline & & Number & $\%$ & & Number & $\%$ \\
\hline $\mathrm{K}^{1}$ & 621 & 614 & 98.9 & 140 & 124 & 88.6 \\
\hline $\mathrm{K} / \mathrm{MS}$ micro ${ }^{2}$ & 621 & 614 & 98.9 & 199 & 176 & 88.4 \\
\hline $\mathrm{K} / \mathrm{MS} \mathrm{vit}^{3}$ & 654 & 648 & 99.1 & 204 & 183 & 89.7 \\
\hline Total & 1896 & 1876 & 98.9 & 543 & 483 & 88.9 \\
\hline
\end{tabular}

Table 2 - Seed germination of Vriesea gigantea on three MS medium-compositions, with different times of cold pre-treatment.

\begin{tabular}{|c|c|c|c|c|}
\hline \multirow{2}{*}{$\begin{array}{c}\text { Pre-treatment } \\
\text { (days) }\end{array}$} & \multirow{2}{*}{ Medium } & \multirow{2}{*}{$\begin{array}{c}\text { Total number } \\
\text { of seeds }\end{array}$} & \multicolumn{2}{|c|}{ Germinated seeds } \\
\hline & & & Number & $\%$ \\
\hline \multirow{3}{*}{0} & $\mathrm{MS}^{1}$ & 263 & 247 & 93.9 \\
\hline & $1 / 2 \mathrm{MS}^{2}$ & 247 & 169 & 64.4 \\
\hline & $\mathrm{MSB}^{3}$ & 228 & 224 & 98.2 \\
\hline \multirow{3}{*}{7} & MS & 254 & 237 & 93.3 \\
\hline & $1 / 2 \mathrm{MS}$ & 251 & 239 & 95.2 \\
\hline & MSB5 & 269 & 264 & 98.1 \\
\hline \multirow{3}{*}{14} & MS & 252 & 225 & 89.3 \\
\hline & $1 / 2 \mathrm{MS}$ & 240 & 232 & 96.7 \\
\hline & MSB5 & 271 & 263 & 97.0 \\
\hline \multirow{3}{*}{21} & MS & 259 & 240 & 92.7 \\
\hline & $1 / 2 \mathrm{MS}$ & 247 & 235 & 95.1 \\
\hline & MSB5 & 280 & 271 & 96.8 \\
\hline Total & & 3061 & 2846 & 93.0 \\
\hline
\end{tabular}

${ }^{\mathrm{MS}}$ full strength, $2 \%$ sucrose, $1.2 \%$ agar, ${ }^{2} \mathrm{MS}$ with macro-nutrients at half strength, $2 \%$ sucrose, $1.2 \%$ agar, ${ }^{3} \mathrm{MS}$ salts, B5 vitamins, $3 \%$ sucrose, $1.2 \%$ agar.

Table 3 - Effect of different medium-compositions on adventitious shoot multiplication of Vriesea gigantea and Vriesea philippocoburgii after four months on multiplication medium.

\begin{tabular}{|c|c|c|c|c|c|c|}
\hline \multirow[b]{2}{*}{ Experiment } & \multirow[b]{2}{*}{ Medium $^{1}$} & \multicolumn{2}{|c|}{ V. gigantea } & \multicolumn{2}{|c|}{ V. philippocoburgii } & \multirow[b]{2}{*}{$\mathrm{P}$ value } \\
\hline & & $\begin{array}{c}\text { Responsive } \\
\text { explants }(\%)\end{array}$ & $\begin{array}{c}\text { Number of } \\
\text { shoots/explant } \\
\text { (mean }+ \text { S.D.) }\end{array}$ & $\begin{array}{l}\text { Responsive } \\
\text { explants }(\%)\end{array}$ & $\begin{array}{c}\text { Number of } \\
\text { shoots/explant } \\
\text { (mean }+ \text { S.D.) }\end{array}$ & \\
\hline \multirow{3}{*}{ I } & $\mathrm{K}$ & 55 & $0.55+0.76 b^{2}$ & 100 & $3.60+1.70$ & \\
\hline & $\mathrm{K} / \mathrm{MS}$ micro & 60 & $1.05 \pm 1.10 \mathrm{ab}$ & 100 & $5.05 \pm 2.26$ & \\
\hline & K/MS vit & 40 & $0.55 \pm 0.76 b$ & 100 & $4.25 \pm 2.53$ & \\
\hline Mean \pm S.D. & & & $0.72 \pm 0.90$ & & $4.30 \pm 2.23$ & $\mathrm{p}<0.001^{3}$ \\
\hline \multirow[t]{2}{*}{ II } & MS & 68 & $3.14 \pm 5.10 \mathrm{a}$ & & & \\
\hline & $1 / 2 \mathrm{MS}$ & 65 & $1.61 \pm 2.59 \mathrm{ab}$ & & & \\
\hline \multirow[t]{2}{*}{ Mean \pm S.D. } & & & $2.38 \pm 3.85$ & & & \\
\hline & $\mathrm{p}$ value & $0.17^{4}$ & $0.047^{5}$ & & $0.25^{6}$ & \\
\hline
\end{tabular}


Favourable effects of its addition to the medium were probably due the adsorption of inhibiting substances derived from the agar (Kohlenbach and Wernicke, 1978), auxins and cytokinins (Weatherhead et al., 1978), chelates (HeberleBors, 1980) and phenolic substances (Fridborg et al., 1978). After transplanting to vermiculite and later to soil, all regenerated plants grew and showed normal phenotypes over more than then months.

Seed of V. gigantea and V. philippocoburgii could be cultured in vitro on Knudson and Murashige and Skoog media, giving rise to adventitious shoots and plants. Seedlings of $V$. gigantea were capable to produce only few adventitious shoots on $\mathrm{K}$ medium. Otherwise, a higher saltconcentration, specially of micro-nutrients, present in MS medium led to higher shoot multiplication rates, being indicated for in vitro culture of this species.

\section{ACKNOWLEDGEMENTS}

We thank to Fundação Zoobotânica do Rio Grande do Sul for supplying the capsules. Statistical analysis were performed by Scatter Consultoria em Estatística. Research support was provided by Fundação de Amparo à Pesquisa do Estado do Rio Grande do Sul (FAPERGS) and Universidade do Vale do Rio dos Sinos (UNISINOS).

\section{RESUMO}

A importância das bromélias como plantas ornamentais e o fato de várias espécies nativas do Rio Grande do Sul estarem ameaçadas de extinção leva ao interesse pela sua micropropagação. Uma cultura in vitro de Vriesea gigantea e Vriesea philippocoburgii foi estabelecida a partir de sementes. A taxa de germinação de $V$. gigantea foi superior à taxa de germinação de $V$. philippocoburgii. Plântulas de V. philippocoburgii deram origem a vários brotos adventíceos quando cultivadas em meio basal de Knudson. Por outro lado, para $V$. gigantea, foi necessária uma maior concentração de sais, sendo que o número de brotos foi aumentado com o meio Murashige and Skoog. A adição de carvão ativado e ácido naftalenoacético ao meio de regeneração permitiu o desenvolvimento de brotos e a formação raízes, confirmando o sucesso da cultura in vitro. A expressão diferencial dos genótipos justifica a necessidade de continuadas pesquisas para que se estabeleçam as condições ideais para os tecidos específicos.

\section{REFERENCES}

Arrabal, R.; Amancio, F.; Carneiro, L. A.; Neves, L. J. and Mansur, E. (2002), Micropropagation of endangered endemic Brazilian bromeliad Cryptanthus sinuosus (L.B. Smith) for in vitro preservation. Biodiversity and Conservation, 11, 1081-1089.

Carneiro, L. A.; Araújo, R. F. G.; Brito, G. J. M.; Fonseca, M. H. P. B.; Costa, A.; Crocomo, O. J. and Mansur, E. (1999), In vitro regeneration from leaf explants of Neoregelia cruenta (R. Graham) L.B. Smith, an endemic bromeliad from Eastern Brazil. Plant Cell, Tis. Org. Cult., 55, 79-83.

Endres, L. and Mercier, H. (2001), Ammonium and urea as nitrogen sources for bromeliads. J. of Plant Physiol., 158, 205-212.

Endres, L. and Mercier, H. (2003), Amino acid uptake and profile in bromeliads with different habits cultivated in vitro. Plant Physiol. and Biochem., 41, 181-187.

Endres, L.; Souza, B. M. and Mercier, H. (2002), In vitro nitrogen nutrition and hormonal pattern in bromeliads. In vitro Cel. and Dev. Biol. - Plant, 38, 481-486.

Fay, M. F. (1994), In what situations is in vitro culture appropriate to plant conservation? Biodiversity and Conservation, 3, 176-183.

Fridborg, G. and Erikson, T. (1975), Effects of activated charcoal on growth and morphogenesis in cells cultures. Physiol. Plant., 34, 306-308.

Fridborg, G.; Pedersén, M.; Landström, L. and Erikson, T. (1978), The effect of activated charcoal on tissue cultures: adsorption of metabolites inhibiting morphogenesis. Physiol. Plant., 43, 104-106.

Gamborg, O. L.; Miller, R. A. and Ojima, K. (1968), Nutrient requirements of suspension cultures of soybean root cells. Exper.Cell Res., 50, 151-158.

Heberle-Bors, E. (1980), Interaction of activated charcoal and iron chelates in anther culture of Nicotiana and Atropabelladonna. Z. der Pflanzenphysiol., 99, 339-347.

Hosoki, T. and Asahira, T. (1980), In vitro propagation of Bromeliads in liquid culture. HortScie., 15, 603-604.

Johansson, L. (1983), Effects of activated charcoal in anther cultures. Physiol. Plant., 59, 397-403.

Knudson, L. (1946), A new nutrient solution for the germination of orchid seeds. American Orchid Society Bulletin, 14, 214-217. 
Kohlenbach, H. M. and Wernicke, W. (1978), Investigations on the inhibitory effect of agar and the function of active carbon in anther culture. Z. der Pflanzenphysiol., 86, 463-472.

Mekers, O. (1976), Zaai en vermeerdering in vitro van Bromeliaceae. Mededelingen Rijksst. $V$. Sierplantenteelt, 37, 11-23.

Mekers, O. (1977), In vitro propagation of some Tillandsioideae (Bromeliaceae). Acta Hortic., 78, 311-320.

Mercier, H. and Kerbauy, G. B. (1992), In vitro multiplication of Vriesea fosteriana. Plant Cell Tis. and Org. Cult., 30, 247-249.

Mercier, H. and Kerbauy, G. B. (1994), In vitro culture of Vriesea hieroglyphica, an endangered bromeliad from the Brazilian Atlantic forest. $J$. Bromeliad, 44, 120-124.

Mercier, H. and Kerbauy, G. B. (1995), The importance of tissue culture technique for conservation of endangered Brazilian bromeliads from Atlantic rain forest canopy. Selbyana, 16, 147-149.

Mercier, H. and Kerbauy, G. B. (1998), Endogenous IAA and cytokinin levels in bromeliad shoots as influenced by glutamine and ammonium nitrate treatments. Rev. Bras. Fisiol. Veg., 10, 225-228.

Mercier, H.; Kerbauy, G. B.; Sotta, B. and Miginiac, E. (1997), Effects of $\mathrm{NO}_{3}^{-}, \mathrm{NH}_{4}{ }^{+}$and urea nutrition on endogenous levels of IAA and four cytokinins in two epiphytic bromeliads. Plant Cell and Environm., 20, 387-392.

Murashige, T. and Skoog, F. (1962), A revised medium for rapid growth and bioassays with tobacco tissue cultures. Physiol. Plant., 15, 473-497.
Pence, V. C. (1999), The application of biotechnology for the conservation of endangered species. In: Benson, E. E. (Ed.). Plant Conservation Biotechnology. London: Taylor and Francis Ltd. pp. 227-250.

Rio Grande do Sul (2003), Decreto no 42.099, de 31 de dezembro de 2002. Declara as espécies da flora nativa ameaçadas de extinção no Estado do Rio Grande do Sul e dá outras providências. Diário Oficial do Rio Grande do Sul, v. 62, n. 1, pp. 1-6.

Weatherhead, M. A.; Burdon, J. and Henshaw, G. G. (1978), Some effects of activated charcoal as an additive to plant tissue culture media. $Z$. Pflanzenphysiol., 89, 141-147.

Received: February 25, 2004; Revised: July 26, 2004; Accepted: March 02, 2005. 